\title{
TarihseI Süreçte İzmir Yahudi Cemaatinin Sosyo-Kültürel ve Ekonomik Durumu
}

Hammet ARSLAN*

\author{
Socio-Cultural and Economic Status
}

of Izmir's Jewish Community in the Historical Process

Citation/C: Arslan, Hammet (2014). Socio-Cultural and Economic Status of Izmir's Jewish Community in the Historical Process, Milel ve Nihal, 11 (1), 119-142.

Abstract: Izmir, because of its advantages, became settlement for different nationalities through the history. The Jews are accepted one of the nationalities lived in Izmir and around. Although the Jews existed in this area since earlier than B.C., their existence intensified by the migration movements at the end of the fifteenth century. In this study we would like to express the socio-cultural and economical status of Izmir's Jewish Community through the historical process. In this context, it will be dealt that the relationships of Jews of Izmir with other ethnical and religious groups, their cultural activities and economical structure.

Key Words: Jews of Izmir, Socio-cultural structure, educational activities, economical status.

Atıf/C: Arslan, Hammet (2014). Tarihsel Süreçte İzmir Yahudi Cemaatinin Sosyo-Kültürel ve Ekonomik Durumu, Milel ve Nihal, 11 (1), 119-142.

* Dr., Dokuz Eylül Üniversitesi, İlahiyat Fakültesi, Dinler Tarihi Anabilim Dalı [hammet.arslan@deu.edu.tr] 
Öz: İzmir, sahip olduğu avantajlardan dolayı, tarih boyunca farklı milletlerin yerleşim alanı olmuştur. İzmir ve civarında yaşayan milletlerden olan Yahudilerin bu bölgedeki varlığı milattan önceye dayansa da 15. yüzyılın sonundaki göç dalgalarıyla yoğunluk kazanmıştır. Bu tarihten sonra Yahudiler cemaatleşmeye başlamış ve kendi kurumlarını oluşturmuşlardır. $\mathrm{Bu}$ çalışmamızda İzmir Yahudi cemaatinin tarihsel süreç içerisindeki sosyo-kültürel ve ekonomik durumunu ortaya koymaya çalışacağız. Bu bağlamda, İzmir'deki Yahudilerin diğer etnik ve dinî gruplarla ilişkileri, kültürel faaliyetleri ve ekonomik yapıları ele alınacaktır.

Anahtar Kelimeler: İzmir Yahudileri, Sosyo-kültürel yapı, eğitim faaliyetleri, ekonomik durum.

\section{Giriş}

İzmir ve civarı, 1lıman iklimi, coğrafî ve jeopolitik konumundan ötürü değişik ırk ve dinlere mensup insanlara ev sahipliği yapmıştır. Geçmişten günümüze Truvalılar, İyonlar, Lidyalılar, Persler, Romalılar, Bizanslılar ve Türkler, İzmir ve çevresine hâkim olmak adına ve bölgeyi korumak için çetin mücadeleler vermişlerdir. ${ }^{1}$ Egemen bir unsur olmamakla birlikte İzmir civarında yaşadığı kabul edilen milletlerden birisi de Yahudilerdir. Kaynaklarda Yahudilerin M.Ö. altıncı yüzyıldan bu yana İzmir çevresinde yaşadıkları belirtilmektedir. Zira I. Babil sürgünündeki esaretten kurtulan Yahudilerden bir kısmının İzmir civarı dâhil olmak üzere Anadolu ve Rumeli'nin değişik bölgelerine dağıldıkları² ifade edilmektedir. Yine, milattan önceki yıllarda İzmir çevresindeki Efes ve Sart bölgesinde Yahudilere ait tapınakların varlığı yukarıdaki tezi ispat mahiyetinde kullanılmaktadır. ${ }^{3}$

1 İzmir'in tarihi hakkında ayrıntılı bilgi için şu kaynaklara bakılabilir: Ekrem Akurgal, Eski İzmir I: Yerleşme Katları ve Athena Tapınağı, Ankara, 1983; Tuncer Baykara, İzmir Şehri ve Tarihi, Ege Üniv., Mat., İzmir, 1974; Emin Canpolat, İzmir: Kuruluşundan Bugüne Kadar, İstanbul, 1954; Akdes Nimet Kurat, Çaka Bey: İzmir ve Civarndaki Adalarn Ilk Türk Beyi (MS 1081-1096), Ankara, 1966; Mübahat S. Kütükoğlu, XV ve XVI. Asırda İzmir Kazasının Sosyal ve İktisâdi Yapısı, İBB Kültür Yayını, İzmir, 2000; Raif Nezihi, İzmir Tarihi, İzmir Büyükşehir Belediyesi Kültür Yay., İzmir, 2001; Necmi Ülker, XVII. ve XVIII. Yüzyıllarda İzmir Şehri Tarihi, Akademi Kitabevi, İzmir, 1994.

2 Eski Ahit' in Yoel kitabında (3/6) yer alan "Yahuda ve Yeruşalim halkını topraklarından uzaklaştırmak için Greklere sattınız" ifadesi Yahudilerin Batı Anadolu'ya köle olarak geldiğini göstermektedir.

3 Ayrıntılı bilgi için bkz., Hikmet Tanyu, Tarih Boyunca Türkler ve Yahudiler, Yağmur Yay., İstanbul, 1976, I/92-95; Abdurrahman Küçük, Dönmeler Tarihi, Rehber Yay., Ankara, 1992, s. 66-67; Avram Galanti, Türkler ve Yahudiler, Tan Mat., İstan- 
Tarihsel Süreçte İzmir Yahudi Cemaatinin Sosyo-Kültürel ve Ekonomik Durumu

Bizans İmparatorluğu döneminde İzmir'de Yahudi varlığına dair net bir bilgi bulunmamaktadır. Yine 1424 yılında Osmanlılar tarafından fethedildiğinde İzmir popüler bir yerleşim bölgesi değildir. Savaş, deprem, yangın, hastalık gibi beşeri ve doğal afetlerin şehre olan ilgiyi azalttığı ileri sürülmektedir. Bu yüzden 15. yüzyılın sonunda İspanya ve Portekiz'deki zulümden kaçarak Osmanlı Devletine sığınan Yahudilerin İzmir yerine daha geniş imkânlara sahip Tire ve Manisa'ya yerleştikleri görülmektedir. ${ }^{4} 16$. yüzyılın başlarında İzmir'deki beş mahalleden dördü Müslümanlara, biri de gayrimüslimlere aittir. Sonraki dönemlerde limandaki ticarî faaliyetlerin artması, şehrin gelişmesine katkı sağlamış ve neticede yeni mahalleler kurulmuştur. Yahudi cemaatinin teşekkülü de bu döneme tekabül etmektedir. ${ }^{5}$ Şehrin ticarî potansiyelinin artması Selanik, Manisa ve Tire' deki Yahudileri İzmir'e yönlendirmiştir. ${ }^{6}$ Ayrıca, İzmir'de yaşayan Yahudiler dinî törenleri icra edebilmek için gerekli 10 yetişkin erkeği (minyan) tamamlayabilmek amaciyla civardaki Yahudileri İzmir'e davet ediyorlar, hatta göç için onları teşvik ediyorlardı. $\mathrm{Bu}$ maksatla cemaat adına toplanan bazı vergilerden onların muaf tutulduğu görülmektedir. ${ }^{7}$

bul, 1947, s. 8-9; Avram Galanti, Fatih Sultan Mehmet Zamanında İstanbul Yahudileri, Fakülteler Mat., İstanbul, 1953, s. 5; Hatice Doğan, Osmanlı Devletinde Hahambaşıllk Müessesesi, Selçuk Üniv. SBE Yüksek Lisans Tezi, Konya, 2002, s. 1; Naim Güleryüz, Türk Yahudileri Tarihi I, Gözlem Yay., İstanbul, 1993, s. 11; Sara Pardo, Sevgili İzmir Beni Tanı: Dünden Yarna İzmir Yahudileri, Etki Yay., İzmir, 2007, s. 10-11, 32.

4 Feridun Emecen, XVI. Asırda Manisa Kazası, TTK Basımevi, Ankara, 1989, s. 53, 62-67; Feridun Emecen, Unutulmuş Bir Cemaat: Manisa Yahudileri, İstanbul, Eren Yay., 1997, s. 30; Siren Bora, İzmir Yahudileri Tarihi (1908-1923), Gözlem Gazetecilik Basın ve Yayın A.Ş., İstanbul, 1995, s. 265; Yusuf Besasel, Osmanlı ve Türk Yahudileri, Gözlem Gazetecilik Basın ve Yayın A.Ş., İstanbul, 2004; Jacob Barnai, "On the History of the Jews in the Ottoman Empire", Sephardi Jews in the Ottoman Empire, Ed. Esther Juhasz, New York, 1990, s. 21-22.

5 Mübahat S. Kütükoğlu, a.g.e., s. 24-27.

6 Esther Benbessa-Aron Rodrigue, Türkiye ve Balkan Yahudileri Tarihi (14.-20. Yüzyıllar), Çev., Ayşe Atasoy, İletişim Yay., İstanbul, 2001, s. 90-91.

7 Ahmet Hikmet Eroğlu, Osmanlı Devletinde Yahudiler, s. 107; Rauf Beyru, a.g.e., s. 10; S. Bora, a.g.e., s. 27. 
XVII. yüzyılın hemen başlarında -tahminen 1605 yılında- İzmir Yahudileri nüfuslarının artmasıyla kendi cemaatlerini kurarak teşkilatlanmaya başlamışlardır. ${ }^{8}$ Cemaat değişik kökenlere sahip göçmenler tarafından zaman içerisinde oluşturulmuş; ${ }^{9}$ ancak sayıca fazla olan Selanik Yahudileri bu sürece ciddi katkı sağlamışlardır. 1620 'ye gelindiğinde kentte altı sinagog bulunuyordu. Bu dönemde farklı bölgelerden olan Yahudi göçmenler arasında dinî açıdan liderlik mücadelesi baş göstermiş ${ }^{10}$ ve bu durum Yahudilerin sosyal ve ekonomik yaşantılarına etki etmiştir. İzmir'e en son gelen Yahudi grubu olan Portekizliler'in öncekilere göre kültürel ve malî açıdan daha iyi durumda oldukları kabul edilmektedir. ${ }^{11}$

İzmir Yahudileri denilince ilk akla gelen ve İzmir Yahudilerinin cemaatleşme sürecinde en dikkat çekici hadise Sabatay Sevi'nin Mesihlik iddiasıyla ortaya çıkışıdır. Mesih inancı Yahudi amentüsünün temel esası olup, sıkıntı içerisinde olan Yahudiler için huzur dolu bir geleceğin hazırlanması anlamına gelir. Gerek İber yarımadasından sürgünün bıraktığı kalıcı izler, gerekse içinde bulunulan kötü yaşam koşulları İzmir Yahudileri arasında Mesihlik iddiası için uygun bir zemin oluşturmuştur. S. Sevi'nin teşebbüsü, din adamlarının karşı çıkışlarına rağmen halk arasında kısmen destek bulmuştur. Fikirlerini yaymak için seyahatler yapan S. Sevi halkı kargaşaya sürüklediği ve merkezi otoriteyi sarsabileceği endişesiyle Osmanlı idaresi tarafından sorguya çekilmiş ve iddialarını ispatlama şansı verilmiştir. Neticede iddialarını ispat edememiş ve Müslüman olduğunu ifade etmek zorunda kalmıştır. ${ }^{12}$ Araştırmacılara göre, İzmir Yahudi cemaati üzerinde sarsıcı bir kriz etkisi yaratan S.

Ahmet Hikmet Eroğlu, a.g.e., s. 107; Mübahat S. Kütükoğlu, a.g.e., s. 33.

Sara Pardo, a.g.e., s. 32.

10 İzmir'deki Yahudi gruplar arasındaki mücadelenin başında hahambaşılık geliyordu. Hahambaşılık kurumu, Yahudi cemaatin oluştuğu dönemden itibaren tesis edilmiştir. İzmir'de ilk hahambaşı İstanbul kökenli bir aileye mensup olan İsak Levi' dir. Selanik Yahudileri onu kabul etmemişler ve Selanik'ten getirdikleri Yosef Eskapa'yı Hahambaşı seçmişlerdir. Bu konudaki tartışmalar hakkında ayrıntılı bilgi için bkz., S. Bora, a.g.e., s. 39-41.

11 S. Bora, a.g.e., s. 39.

12 Sabatay Sevi'nin mesihlik iddiası hakkında ayrıntılı bilgi için bkz., Abdurrahman Küçük, Dönmeler Tarihi, Rehber Yay., Ankara, 1992; Gershom Scholem, Sabetay Sevi: Mistik Mesih 1626-1676, Çev. Eşref Bengi Özbilen, Kabalcı Yay., İstanbul, 2011. 
Sevi, yoldan sapmış bir sahtekâr, garip tavırlara sahip manik-depresif bir kişilik ve meşhur olmak sevdasına kapılmış zavallı bir ruh hastası olarak tanımlanmaktadır. ${ }^{13}$

İşte bu koşullar içerisinde varlığını sürdüren İzmir Yahudileri dinî ve sağlık ihtiyaçlarını kendi cemaatleri içerisinde karşılayabilmek amacıyla bazı kurumlar ve hastaneler kurmuşlardır. Ayrıca yoksul kesimin temel ihtiyaçlarını karşılamak ve onları kalkındırmak için de bir takım yardım kuruluşları oluşturmuşlardır. ${ }^{14}$ Şimdi, İzmir Yahudilerini daha iyi analiz edebilmemiz için tarihsel süreç içerisinde onların şehirde yaşayan diğer milletlerle sosyal ilişkilerine değinmek istiyoruz. Yahudilerin giyim kuşamları, eğitim faaliyetleri, basın-yayın ve matbaacılık konusundaki gayretleri hakkında bilgiler verdikten sonra ekonomik durumlarını ortaya koymaya çalışacağız.

\section{I. İzmir Yahudilerinin Diğer Etnik Gruplarla İlişkileri}

İzmir, Osmanlı Devletinin çok cemaatli yapısını yansıtan en karakteristik şehirlerinden birisi olmuştur. Burada Türk, Rum, Ermeni, Yahudi ve Frenkler bir arada yaşamaktayd $1 .{ }^{15}$ İzmirlilerin konuksever oldukları birçok yazar ve gezgin tarafından anlatılmaktadır. Türklerin başını çektiği bu anlayış, aynı ortamda yaşayan Yahudiler tarafından da benimsenmiştir. ${ }^{16}$ İzmir Yahudi cemaati, diğer Osmanlı kentlerinde yaşayan Yahudilere göre farklı bir yapıya sahip olmuş; hem Sefarad geleneklerine bağlı kalmış hem de Osmanlı'nın genel özelliklerini benimseyerek özgün bir yapı oluşturmuşlardır. İzmir' in ticarî açıdan önemli bir liman kenti olması ve etnik/kültürel çeşitliliği barındırması bunda önemli bir etkendir. Çünkü kent halkı aynı ortamda, benzer koşullarda yaşıyor ve aynı havayı teneffüs

13 Henri Nahum, a.g.e., s. 34, 61, 243; Esther Benbessa-Aron Rodrigue, a.g.e., s. 167; Abdurrahman Küçük, a.g.e., s. 262, 265.

14 İzmir Yahudilerine ait kurumlar hakkında ayrıntılı bilgi için bkz., Mine Tanaç, "İzmir Havraları", Ege Mimarlk Dergisi, 2001/2-3, Sayı: 38-39, Mimarlar Odası İzmir Şb., Yay., İzmir, 2001; Mine Tanaç Zeren, İzmir'de Sefarad Mimarisi ve Sinagogları, Yalın Yay., İstanbul, 2010; Hammet Arslan, “Tarih Boyunca İzmir Yahudileri: Yedi Kiliseler, Sürgün, Cemaatleşme Süreci ve Modern Durum", Bütün Yönleriyle Yahudilik Sempozyumu (18-19 Şubat 2012), Türkiye Dinler Tarihi Derneği, Ankara, 2012, s. 187-217.

15 Henri Nahum, İzmir Yahudileri: 19.-20. Yüzyıl, Çev: Estreya Seval Vali, İletişim Yay., İstanbul, 2000, s. 11.

16 Rauf Beyru, 19. Yüzyılda İzmir'de Yaşam, Literatür Yay., İstanbul, 2000, s. 101. 
ediyordu. Ancak dostane ortamın siyasî, ticarî ve dinî sebeplerden ötürü Yahudilere özellikle Rum ve Ermenilerin bazen düşmanca bir tutum sergilediği anlar olmuştur. ${ }^{17}$

İzmir Yahudi cemaatinin Batılılarla olan ilişkisinin temelinde ticarî faaliyetler yer almaktadır. İran'dan getirilen ipek ve dokumalar, Anadolu'nun değişik yerlerinden gelen ürünler, Menderes ve Gediz havzasında yetiştirilen tarımsal ürünler (incir, zeytin, tütün, pamuk vs) İzmir limanından yurt dışına yollanıyordu..$^{18}$ İspanya ve Portekiz göçmeni Yahudiler kentte ticaretle uğraşan Venedikli, Ceneviz, Hollandalı, Fransız ve İngiliz tüccarların danışmanlığını ve tercümanlığını yapıyorlardı. Yahudiler zamanla kazandıkları tecrübelerle ticarî faaliyetlere adım atmışlar ve Batılılara rakip olmuşlardır. Bu rekabetten rahatsız olan Batılılar, Yahudileri "Kan İsnadı"19 ile suçlamışlardır. İzmir Yahudi cemaatinin Batılılarla olan ilişkisinin bir diğer boyutunu, Hıristiyan misyonerlik faaliyetleri oluşturmaktadır. Hıristiyanlar için İzmir gerek tarihteki önemi ve gerekse jeopolitik konumu açısından Anadolu ve Doğu Akdeniz'e açılan bir kapı konumundaydı. Etkin misyonerlik için okullar, klinikler, kitapçılar ve matbaalar açılmıştır. Misyonerler ilk hedef olarak Yahudileri seçmişlerdir. Misyonerlerin Yahudi yaşam tarzına uygun hareket etmeleri ve bunu bir metot olarak benimsemeleri bildirilmiştir. Ayrıca yoksullara maddi yardım, karşılıksız eğitim ve sağlık hizmeti veriliyordu. ${ }^{20} 1870^{\prime}$ li yıllarda Kilise misyon heyeti, İzmir'de

17 Bu konuda örnekler ve ayrıntılı bilgi için bkz., Siren Bora, İzmir Yahudileri Tarihi (1908-1923), Gözlem Gazetecilik Basın ve Yayın A.Ş., İstanbul, 1995, s. 81-83.

18 Henri Nahum, a.g.e., s. 16-17.

19 Batılılar, Fısıh (Pesah/Hamursuz) bayramında yedikleri mayasız ekmeği Hıristiyan kanı ile yaptıklanı gerekçesiyle Yahudileri suçlamışlardır. Kanaatimizce bu suçlamanın dinî kaynağı İsa Mesih'in Yahudilerce çarmıha gerilişidir ve tarih boyunca bundan kaynaklanan olayları görmek mümkündür. Osmanlılar Döneminde "Kan İsnadları" hakkında ayrıntılı bilgi için bkz., Ahmet Hikmet Eroğlu, Osmanlı Devletinde Yahudiler (XIX. Yüzyılın Sonuna Kadar), Alperen Yay., Ankara, 2000, s. 221-229; Jacob Barnai, "Blood Libels in the Ottoman Empire of the Fifteenth to Nineteenth Centuries", Antisemitism Through the Ages, Jerusalem, s. 189; S. Bora, a.g.e., s. 83-85.

20 İzmir'de görevlendirilen misyonerlerin kurumlarına gönderdikleri raporlar ve kaleme aldıkları anılardan ilk hedefin Yahudiler olduğunu ve bunun için yöntemler geliştirildiğini, hatta Yahudilerin pis ve yalancı olarak aşağılandığını görmek mümkündür. S. Bora, a.g.e., s. 85-89. 
Tarihsel Süreçte İzmir Yahudi Cemaatinin Sosyo-Kültürel ve Ekonomik Durumu aktif çalışmalarda bulunmuş; bu amaçla okullar ve klinikler açmışlardır. ${ }^{21}$ Yahudilerin kendi geleneklerine içten bağlılıkları ve dış etkilere kapalı oluşları misyonerlerin başarılı olma şanslarını azaltmıştır.

İzmir Yahudi cemaatinin Ermenilerle olan ilişkileri bazen sorunlu bazen normal olarak seyretmiştir. Sorunun kaynağı büyük ölçüde ekonomik sebeplerdir. Zira Ermeniler Yahudilere çalışabilecekleri iş alanları bırakmamışlardır. Aslında Ermenilerin kentteki en sorunlu etnik grup oldukları ve bütün gruplarla problemleri olduğu söylenir. Nitekim Gregoryen Ermenilerle, Katolik Ermeniler arasında dahi bir takım sorunların olduğu belirtilmektedir. ${ }^{22}$ Ermeniler, ekonomik alandaki rekabette başarılı olabilmek için Yahudilere "Kan İsnadı" gibi suçlamalar yöneltmişlerdir. Bu durum iki cemaat arasındaki ilişkileri olumsuz yönde etkilemiştir. ${ }^{23}$ Bazı gezginler bu durumu "dinsel düşmanlıktan çok, ticarî rekabetten kaynaklanan kin dolu duygular beslenmektedir" 24 biçiminde ortaya koymuşlardir.

İzmir Yahudilerinin Rumlarla olan ilişkilerinin şekillenmesinde ise, öncelikle ekonomik faktörler, sonra da dinî ve siyasî faktörler rol oynamıştır. ${ }^{25}$ İzmir limanının ticarî öneminin artması neticesinde gelişen ekonomik canlanmadan pay alma çabası iki cemaat arasındaki çatışmaları körüklemiştir. Rumlar bu rekabette siyasî ve dinî

21 James Hastings Nichols, History of Christianity (1650-1950): Secularization of the West, The Ronald Press Company, New York, 1956, s. 318.

22 Paul Lindau, "1900’lerde İzmir" Türk Dünyası Araştırmaları, çev. Selçuk Ünlü, İstanbul, s. 179.

23 S. Bora, a.g.e., s. 89-91; Rauf Beyru, a.g.e., s. 150-151; Esther Benbessa-Aron Rodrigue, Türkiye ve Balkan Yahudileri Tarihi (14.-20. Yüzylllar), Çev., Ayşe Atasoy, İletişim Yay., İstanbul, 2001, s. 338.

24 George Rolleston, Report on Smyrna, printed by George E. Eyre and William Spottiswoode, London, 1857, s. 34'ten aktaran Rauf Beyru, a.g.e., s. 144.

25 H. Nahum'a göre, İzmir Yahudilerinin en sorunlu olduğu cemaat Rumlardır. Yahudilerin, Ermeniler ile olan problemlerin dinî kaynağı olan "Kan İsnadı" Rumlar için de geçerlidir. "Yahudilerin bayramlarda çocuk kanına ihtiyaç duydukları" yönündeki benzer iddialara Rumlar arasında da rastlanılmaktadır. Hatta bu anlayış iki cemaat arasında ciddi olayların ortaya çıkmasına sebep olmuştur. Henri Nahum, a.g.e., s. 87-96; S. Bora, a.g.e., s. 91-93; Rauf Beyru, a.g.e., s. 150-151; Esther Benbessa-Aron Rodrigue, a.g.e., s. 338. 
olayları kendi lehlerinde kullanmaya çalışmışlardır. ${ }^{26}$ Yahudilerin Ermeni ve Levantenlerle ilişkileri genel olarak normal düzeyde olmasına rağmen Rumlarla ilişkileri sorunlu olmuştur. A. Galante bu durumu "İzmir Yahudilerinin Rumlarla ilişkileri pek de arzulanan nitelikte değildir. Rumların Yahudilere karşı sürdürdükleri dinsel nefret, bu iki grup arasında içten ilişkilerin kurulmasını engellemiş ve zaman zaman üzücü olayların doğmasına neden olmuştur" 27 biçiminde ifade eder. İzmir'de Yahudi-Rum ilişkisi açısından şu ifadeler dikkat çekicidir:

Özellikle, papazların da teşvikiyle belirli dinsel bayram günlerinde büsbütün heyecana kapılan Rumların bulunduğu bir mahalleden bir Yahudi'nin en azından dayak yemeden geçebilmeyi göze alabilmesi, anlatımlara bakılırsa pek de mümkün olmamaktadır. ...Bu tür olaylar yalnızca İzmir ve Türkiye' de değil Yunanistan, Macaristan, Romanya ve Rusya' da da vuku bulmakta idi. ${ }^{28}$

Kurtuluş savaşının bittiği yıllarda Yunan kuvvetleri İzmir ve civarını terk ederken Türklerinkini olduğu kadar Yahudilere ait birçok evi de yakmıştır. ${ }^{29}$

Osmanlı Devletinin, İzmir Yahudi cemaati ile olan ilişkisi ise, Ermeni ve Rumlara göre daha sıcak ve dostane olmuştur. Osmanlı halkı onlara daima hoşgörü ile yaklaşmıştır. Batılılar ve diğer cemaatler tarafından yöneltilen dinî suçlamalar karşısında, Osmanlılar daima Yahudileri korumuşlardır. Zaten İzmir'de olduğu gibi diğer Osmanlı şehirlerinde de Türkler ile Yahudiler komşu olarak yan yana yaşamışlar ${ }^{30}$ ve Yahudi gettoları olmamıştır. Sosyal, kültürel ve ekonomik hayat gayet olumlu ve barışçıl bir hava içerisinde sürüp gitmiştir. Türk ve Yahudi çocukları aynı okullarda okuyor, aynı

26 Rumlar arasında, Yahudilerin “İsa Mesih'i çarmıha geren” kimseler olduğu yönünde yaygın bir kanaat hâsıl olmuştur. Siyasî açıdan ise, Yunanistan'ın bağımsızlığını kazanma çabaları esnasında Yahudilerin Türkleri destekledikleri gerekçesiyle tartışma ve çatışmalar artmıştır. S. Bora, a.g.e., s. 91-93.

27 A. Galante, Histoire de Juifs d'Anatolie, des Juifs d'Izmir, Imprimerie M. Bakok, İstanbul, 1937, s. 27'den aktaran Rauf Beyru, 19. Yüzyılda İzmir'de Yaşam, Literatür Yay., İstanbul, 2000, s. 143.

28 Rauf Beyru, a.g.e., s. 150.

29 Rıfat B. Bali, Cumhuriyet Yıllarında Türkiye Yahudileri: Bir Türkleştirme Serüveni (1923-1945), İletişim Yay., İstanbul, 2001, s. 34.

30 Rauf Beyru, a.g.e., s. 89, 143, 155. 
Tarihsel Süreçte İzmir Yahudi Cemaatinin Sosyo-Kültürel ve Ekonomik Durumu ortamda çalışıyor ve bir araya gelip konuşuyorlard1. ${ }^{31}$ İki topluluk arasındaki sorun Yahudi gençlerin, özellikle kızların, İslam'a girmesi olmuştur. Genç kızlar ya âşık olarak ya da maddi açıdan rahatlığa kavuşacakları düşüncesi ile Müslüman gençlerle evlenmeyi tercih etmişlerdir. 1903'te 13, 1907' de 5 (3'ü kız), 1908' de de 8 Yahudi İslam'a girmiştir. ${ }^{32}$ Cumhuriyet yıllarında bu sayının daha da arttığı ifade edilmektedir. ${ }^{33}$

20. yüzyıl başlarında İzmir Yahudilerinin kendi aralarında ç1kan bir sorunu veya diğer cemaatlere mensup birisiyle olan problemlerini halletmek için Şer'iyye mahkemelerine müracaat ettiklerini gösteren kayıtlar mevcuttur. Bu, onların kadıların tarafsızlığına güvendiklerini gösteren bir durumdur. ${ }^{34} 1908$ İzmir Şer'iyye Sicillerine göre Yahudilerin 3 dava açtıkları; 10 miras işlemlerinin çözüme kavuşturulduğu; 19 kez Vekâlet sözleşmesi yaptıkları görülmektedir. Sicillerden, Yahudilerin Karataş, Göztepe, Abdullah Efendi, Hahambaşı, Hurşidiye, Havra gibi bölgelerde yaşadıkları; tüccarlık, kasaplık, unculuk, tercümanlık gibi meslekleri icrâ ettikleri anlaşılmaktadır. ${ }^{35}$

İzmir Hahambaşılığ 1909 tarihinden itibaren Doğum ve Evlilik Defterleri adı verilen kayıtlar tutmaya başlamıştır. ${ }^{36}$ İzmir Haham-

31 Halid Ziya Uşaklıgil, Kırk Yıl, Özgür Yay., İstanbul, 2008, s. 140-142.

32 S. Bora, a.g.e., s. 93-95. Kayıtların yeniden incelenmesi gerektiği kanısındayız. Çünkü yazar ileriki sayfalarda, 1908'de İslam'a girenlerin sayısının 7 olduğunu ifade etmiştir. S. Bora, a.g.e., s. 106. Bir genç kızın Yahudilikten İslam'a geçişi için yapılan tören ve İzmir'de Türk-Yahudi ilişkileri hakkında daha ayrıntılı bilgi için bkz., Halid Ziya Uşaklıgil, İzmir Hikayeleri, Özgür Yay., İstanbul, 2005, s. 171, 214.

33 Rifat B. Bali, a.g.e., s. 219-220.

34 Dava dilekçelerinin örnekleri ve Yahudilerin miraslarının feraiz usulüne göre taksimini gösteren kayıtlar için İzmir Şer'iyye sicilleri Defter no 92, s. 101/6; no 92, s. 6/a; no 93, s. 112/c-113/a'ya bakılabilir. Bu kayıtların Latinize edilmiş halleri için bkz., S. Bora, a.g.e., s. 102-105.

35 İzmir Şer'iyye Sicillerine göre Yahudilerin kimlik bilgileri, oturdukları yer ve isimlerini gösterir tablo; Yahudiler tarafından açlan davaların tarihi, konusu, dava sahibinin ismi, adresi ve mesleğini gösterir tablo; miras işlemlerine konu olan tereke, davacının adres ve mesleğini gösterir tablo; vekalet sözleşmesinin tarihi, konusu, davacının adı, adresi ve mesleğini gösterir tablo için bkz., S. Bora, a.g.e., s. 106-114.

36 İzmir Hahambaşılığı Evlilik Defteri'ne göre, 1910-1922 yılları arasında evliliklerin sayısı, evlenenlerin medeni hali; Doğum Defterine göre doğumların sayısını gösteren tablo için bkz., S. Bora, a.g.e., s. 116-118. İzmir Yahudi cemaatini, 90 
başılı̆̆ Evlilik Defterine göre, 1909-1922 yılları arasında Osmanlı s1nırları içindeki başlıca Yahudi yerleşimleri ve buralardan İzmir'e kaç kişinin göç ettiğini gösteren tablo şu şekildedir ${ }^{37}$ :

\begin{tabular}{|c|c|c|c|c|c|c|c|}
\hline$\underline{\text { Kent }}$ & $\underline{\text { Sayı }}$ & $\underline{\text { Kent }}$ & $\underline{\text { Sayı }}$ & $\underline{\text { Kent }}$ & $\underline{\underline{\text { Sayı }}}$ & $\underline{\text { Kent }}$ & $\underline{\text { Sayı }}$ \\
\hline Aydın & 79 & Tire & 54 & Manisa & 50 & Kasaba & 50 \\
\hline İstanbul & 23 & Selanik & 20 & Milas & 19 & Yenişehir & 19 \\
\hline Rodos & 18 & Menemen & 17 & Bergama & 16 & Urla & 15 \\
\hline İstanköy & 14 & Foça & 10 & Bursa & 9 & Girit & 9 \\
\hline Larissa & 8 & Yanya & 7 & Alanya & 6 & Edirne & 6 \\
\hline Sakız & 6 & Akhisar & 5 & Odessa & 5 & Kudüs & 5 \\
\hline Kırkağaç & 4 & Nazilli & 4 & Salihli & 4 & Bağdat & 4 \\
\hline Bayındır & 3 & İştib & 3 & Sofya & 3 & Hanya & 2 \\
\hline Çanakkale & 2 & Denizli & 2 & Halep & 2 & Germencik & 2 \\
\hline Çeşme & 2 & Korfu & 2 & Bodrum & 2 & Nevşehir & 2 \\
\hline Pliska & 1 & Bükreş & 1 & Adana & 1 & Şiraz & 1 \\
\hline Kirgosiro & 1 & Kalos & 1 & Soma & 1 & Emet & 1 \\
\hline Haskova & 1 & Kavala & 1 & Samakov & 1 & Söke & 1 \\
\hline
\end{tabular}

Her geçen gün nüfusları azalan ${ }^{38}$ İzmir Yahudilerinin günümüzde sayıları 1500'lere kadar inmiş bulunmaktadır. Nüfusun azalmasının temel nedeni, gençlerin eğitim ve iş (ticaret, ekonomi, bilişim, tıp vb) sahasında etkili olabilmek için Türkiye'nin (İstanbulAnkara) ve dünyanın (Avrupa ülkeleri, Amerika, Çin ve Hindistan) değişik yerlerine gidip geri dönmemeleri gösterilmektedir. ${ }^{39}$ Ayrıca, nüfusun yaşlanması ve doğum oranlarının azalması da bu durumu etkilemektedir. İzmir Yahudi cemaatinin günümüzde İstanbul'daki Yahudilerle, Batı dünyası ve İsrail ile ilişkileri gayet iyi durumdadır.

yaşlarında olan baş haham Rabbi Nisim Barmaymon'un evinden idare etmesi ve sağlığının yerinde olmaması nedeniyle bu konuda güncel kayıtlara ulaşamadığımizı ifade etmek isteriz. S. Bora, a.g.e., s. 124.

38 İzmir Yahudilerinin sayıları 1948 'de İsrail'e ve Batı'ya göç etmeleri nedeniyle 2.500'e; 2000'li yılların başlangıcından itibaren de 2000'e düşmüştür. Güncel bilgiler, Alsancak'taki Şaar Aşamayim sinagogunda hazanlık yapan Moti (Mordehay) Katan ile yapmış olduğumuz söyleşiye (13 Şubat 2012) dayanmaktadır.

39 Bu durum cemaatte bir dönüşüm meydana getirmektedir. Hale Okçay, "İzmir Yahudileri: İşadamlarının Kimliğinin Dönüşümü", Sosyoloji Dergisi, (17), İzmir, s. 191-192. 


\section{II- İzmir Yahudilerinin Giyim Tarzları}

Osmanlılar döneminde gayrimüslimlerin giyecekleriyle ilgili olarak renk, kullanılan malzeme ve kesim açısından bir takım sınırlamalar vardı ve bu durum fermanla ilan ediliyordu. ${ }^{40}$ Mesela Yahudilerin yeşil ve beyaz kullanmaları yasaktı. Müslümanlar sarı, Yahudiler siyah ayakkabı giymek zorunda idi. İpek, tülbent, ince yün dokuma kumaşlar ve pahalı kürk yasaktı. Giysilerin genişliği ve uzunluğu da kurallarla belirlenmişti. Kurallara uymayanlar cezalandırıl1yordu. Giyim konusundaki kurallar sadece Yahudiler için değil bütün gayrimüslimler için geçerliydi. ${ }^{41}$

Osmanlı dönemindeki Yahudiler giyim tarzları açısından yerliler ve İber yarımadasından sürgün edilenler olarak ikiye ayrılmışlardı. Yerliler türban takarken göçmenler kenarsız şapka giyiyorlardı. İstanbul cemaati 19. yüzyıl sonunda geleneksel giyimi terk etmişken, İzmir cemaati 20. yüzyıl başlarında giyim konusunda geleneklerini koruyorlard1. ${ }^{42} \mathrm{Bu}$ durum İzmir Yahudi cemaatinin dinî otoritelerin daha fazla etkisinde kaldıklarının bir göstergesi şeklinde yorumlanmaktadır. Din adamları cemaati geleneklere uyma konusunda sürekli uyarıyorlar, uymayanları dinsizlikle itham ediyorlar ve Tanrı'nın cezasına çarptırılacaklarını söylüyorlard1. ${ }^{43}$

20. yüzyılın başlarında İzmir Yahudilerinin giyim tarzları üzerinde Osmanlı etkisini görmek mümkündür. Kadınlar şemiz adı verilen gömlek, altına şalvar tipi pantolon, üzerine uzun bir entari ve onun üzerine ceket giyiyor ve kuşak bağlıyorlardı. Erkekler ise fes, mavi veya siyah şalvar, kuşaklı entari, yelek, cübbe, siyah ayakkabı

40 Osmanlılarda, gayrimüslimlerin giyim kuşamları, nerede yaşayacakları ve evlerinin biçimleri yasalarla belirlenmiştir. Bu konuda bkz., Ahmet Hikmet Eroğlu, a.g.e., s. 12-15, 17-19; Bilal Eryılmaz, Osmanl Devletinde Gayrimüslim Teb'anın Yönetimi, Risale, İstanbul, 1990, s. 18-23.

41 İzmir Yahudilerinin giyinme, temizlenme ve süslenmelerine dair anlatımlar için bkz., Rauf Beyru, a.g.e., s. 194-196; S. Bora, a.g.e., s. 79; Sara Pardo, Sevgili İmir Beni Tanı: Dünden Yarına İzmir Yahudileri, Etki Yay., İzmir, 2007, s. 113-115.

42 19. yüzyıl sonunda Halid Ziya Uşaklıgil'in İzmir'deki Yahudi kadınlarını tasvirleri için bkz., H. Z. Uşaklıgil, İzmir Hikayeleri, s. 173; S. Bora, a.g.e., s. 80; Henri Nahum, a.g.e., s. 210.

43 Bu konuda halkın tutumu ve din adamlarının onlara karşı yaptıkları uyarılar için bkz. S. Bora, a.g.e., s. 79-80. 
ve dua örtüsü (tallit) giyiyorlardı. Hahamların tek farkı ise cübbelerinin daha geniş olmasıydı. ${ }^{44}$ Günümüzde ise, İzmir Yahudi cemaati üyelerinin giyim tarzlarının diğer vatandaşlarınkinden bir farkı olmadığı gözükmektedir. Yahudiler ibadet esnasında gündelik kıyafet giyerken, hahamların özellikle düğün törenleri esnasında özel kıyafetler giydikleri dikkati çekmektedir.

\section{III- İzmir Yahudilerinin Kültürel Durumları}

Osmanlı idaresindeki Yahudi cemaati, II. Mehmet zamanında sistemli hale getirilen tam bir inanç, ibadet ve eğitim özgürlügüne sahipti. ${ }^{45}$ İzmir, çok dilli ve çok milletli yapısı ile zengin bir kültür mozaiği görünümünde idi. Bu zenginliğe Yahudiler hem katkı yapmışlar hem de bundan istifade etmişlerdir. 1850'li yıllara kadar İzmir'de Havralar (Hevrot veya Talmud Tora) ve Din Akademileri (Yeşivot) olmak üzere iki türlü Yahudi eğitim kurumu vardı. İlkokul olarak kabul edilebilecek Havralarda temel matematik ve temel dinî eğitim veriliyordu. Havralara bitişik olarak kurulan Din Akademilerinde ise üst seviyede din eğitimi verilmekteydi. ${ }^{46}$ Eğitim büyük ölçüde dinî temelli idi ve eğitim işleri genel olarak din adamlarının idaresindeydi. Eğitimi modernize etme konusundaki yetersizlik, etkili idarecilerin yetişmeyişi, 18. yüzyıldan itibaren Yahudilerin bir takım sıkıntılarla karşılaşmasının zeminini hazırlamıştır. Aynı dönemde Rumlar ve Ermeniler Batılı eğitim kurumlarında okuyup, kazandıkları dil becerisini ve teknik imkânları kendi gruplarının kalkınmasında kullanmışlardır. Dolayısıyla eğitim açısından geride olan Yahudilerin sosyal ve ekonomik hayatta diğer gruplarla rekabet etmesi imkânsızlaşmıştır. ${ }^{47}$

$44 \quad$ S. Bora, a.g.e., s. 81; Sara Pardo, a.g.e., s. 113-114; Hale Okçay, İzmir Yahudi Cemaati Kadın Kimliği, Phoenix, Ankara, 2013. İzmir' de bir Yahudi kadınını, kızını, erkeği, gelinini gösteren resimler için bkz., Rauf Beyru, a.g.e., s. 45, 86-88, 90.

45 Avigdor Levy, The Sephardim in the Otoman Empire, Darwin Press, New Jersey, 1992, s. 15-19; Bilal Eryılmaz, Osmanlı Devletinde Gayrımüslim Teb'anın Yönetimi, Risale, İstanbul, 1990, s. 22.

46 Bu okullar 1850 'li yıllara kadar hizmet vermiştir. S. Bora, a.g.e., s. 153; Sadiye Tutsak, a.g.e., s. 50.

47 1800'lü yıllarda Yahudi eğitim kurumlarının yapısı hakkında Batılı gezginlerin görüşleri için bkz., S. Bora, a.g.e., s. 153-155. 
Tarihsel Süreçte İzmir Yahudi Cemaatinin Sosyo-Kültürel ve Ekonomik Durumu

Tanzimat Fermanı ile uygulamaya konulmak istenilen eğitim politikasının kabul görmemesinin ${ }^{48}$ ardından Islahat Fermanı ile gayrimüslimlerin Rüşdiyelere girişine ve kendi kültürlerini ve dillerini öğretmelerine izin verilmiştir. ${ }^{49}$ Mühendishane-i Bahr-i Hümayun (1773), Mühendishane-i Berr-i Hümayun (1796) ve Tibhanei Amire (1827) gibi yüksek okullar bütün öğrencilere açı idi. Tibhane-i Amire'de 1874'te 15 Yahudi öğrencinin okuduğu belirtilmektedir. ${ }^{50}$ Lise dengi bir devlet okulu olan İzmir Mekteb-i İdadi'sinden 1891 yılında 12 Türk, 3 Yahudi öğrenci mezun olmuştur. ${ }^{51}$ Aynı dönemde Evrensel İsrail Birliği (Alliance Israelite Universelle ${ }^{52}$ ) ülke genelinde elli civarında okul açmıştır. Paris'e bağlı olan bu okulların denetimleri de oradan yapılmaktaydı. Paris'teki komite, okul müdürlerinden gelen raporlara göre okulların ve sınıfların yapısı, yeni okullar açıp açmayacağı, kimlerin göreve devam edip etmeyeceği hakkında nihai kararı veriyordu. ${ }^{53}$ Halid Ziya, İzmir'deki okulun kışla kadar büyük, devasa kargir bir bina olduğunu, Yahudi gençlerin eğitildiğini, seçilen zeki öğrencilerin üst düzey eğitim için Paris'e gönderildiğini belirtir. ${ }^{54} 1905$ yılında İzmir'de Rüşdiye (orta dereceli) derecesinde üç Yahudi Okulu vardı. Bunlardan Alyans erkek okulunun 260, k1z okulunun 291, Terakki karma okulunun da 90 erkek, 70 kız öğrencisi vardı. 1908 yılında 37 adedi ilk, 5 adedi de orta dereceli olmak üzere 42 Yahudi Okulu vard1. ${ }^{55}$ Yahudi cemaati başlangıçta kendi eğitim dillerini kullanmalarına rağmen 20. yüzyılın

48 Osmanlı idaresi Tanzimat Fermanı ile gayrimüslim cemaatlere ait okullar üzerinde denetim kurmak istemiş ancak din adamlarının direnişi ve protestosu ile karşılaşmıştır. Cemil Koçak, "Tanzimattan Sonra Özel ve Yabancı Okullar", Tanzimattan Cumhuriyete Türkiye Ansiklopedisi, II/485-486.

49 Bayram Kodaman, Abdülhamit Devri Ĕ̆itim Sistemi, İstanbul, 1980, s. 43; Cemil Koçak, “a.g.m.", s. 485.

50 Aynı dönemde bu okulda 300 Türk, 40 Rum ve 29 Ermeni öğrenci eğitim görüyordu. S. Bora, a.g.e., s. 157.

51 S. Bora, a.g.e., s. 157-158.

52 Bundan böyle "Alyans" olarak ifade edilecektir.

53 Avram Galanti, Türkler ve Yahudiler, s. 158-159; Henri Nahum, a.g.e., s. 104-105, 110-111.

54 H. Z. Uşaklıgil, İzmir Hikâyeleri, s. 59-60.

55 Okullar hakkında ayrıntılı bilgiyi gösteren tablolar için bkz., S. Bora, a.g.e., s. 160162. Ayrıca, 1891, 1894, 1908'de İzmir' de yer alan Yahudi mekteplerinin isimleri, eğitim türleri (kız-erkek-karma) ve bulundukları yerleri gösterir tablo için bkz., Sadiye Tutsak, İzmir'de Eğitim ve Eğitimciler, s. 236-239; M. Hidayet Vahapoğlu, Osmanlı'dan Günümüze Azınlı ve Yabancı Okullar, MEB Yay., İstanbul, 2005 
başlarından itibaren çıkarılan yasalara uymuşlar ve Türkçenin öğrenilmesi ve yaygınlaştırılması yönünde çaba harcamışlardır.

1927 yılında bütün Türk okullarının Yahudi çocuklarına açık olduğu Milli Eğitim Bakanlığı tarafından ilan edilmiştir. Ayrıca İstanbul, İzmir, Edirne ve Kırklareli'ndeki Yahudi okullarına hükümet bütçesinden yardımlar yapılmıştır. ${ }^{56}$ 1922-1923 ders yılında beş adet Yahudi mektebi faaliyete geçmiştir. 1927-1928 ders yılında mektep sayısı dörde, 1941 'de ise üçe düşmüştür. Aynı tarihte Türkiye sınırları içerisinde İstanbul'da dört Yahudi mektebi vard1. ${ }^{57}$ Günümüzde İzmir Yahudi Cemaatinin çocuklarının büyük çoğunluğu başta özel kolejler olmak üzere Türk okullarında eğitim görmektedirler.

İzmir, sahip olduğu kozmopolit yapı nedeniyle yabancı dilde basının geliştiği ilk Osmanlı kenti olmuştur. 1842 yılında İzmir Yahudilerinden Rafael Uziel Pinşerle, Judeo İspanyolca ${ }^{58}$ "La Buena Esperansa" (Güzel Umut) gazetesini çıkarmıştır. Kısa süreli bu gazetenin yerine 1846' da "La Puerto del Oriente" (Doğu Limanı) gazetesi çıkarılmaya başlanmıştır. ${ }^{59}$ Diğer milletlere ait basın kuruluşlarının İstanbul'a taşınması ile Yahudi basını da İstanbul'a taşınmak zorunda kalmıştır. Gazete yazılarında yorumdan çok malumata yer veriliyor; idarecilerle ilgili sevgi ve saygı ifadeleri sıkça yer alıyordu. 1857 yılında çıkarılan "Matbaa Nizamnamesi" ile basın-yayın organları denetlenmeye başlanmıştır. 1870'li yıllarda İzmir'de Yahudi gazetesi sayısı artmıştır. ${ }^{60} 19$. asrın sonlarında sekiz gazeteden [Şarkiyye, Zeman, Eride-i Erkece, Ceride-i Lisan, Üstad,

56 Avner Levi, Türkiye Cumhuriyeti'nde Yahudiler: Hukuki ve Siyasi Durumları, İletişim Yay., İstanbul, 1996, s. 86. 1927-1945 yılları arasında Yahudi okulları ve okullarda eğitim gören öğrenci sayısını gösteren tablo için bkz., Rıfat B. Bali, a.g.e., s. 401.

57 1922-1923 ve 1933-1934 ders yılında faal olan mekteplerdeki derslik ve öğrenci sayısını gösterir tablolar için bkz., Sadiye Tutsak, a.g.e., s. 383-384.

5819 ve 20. yüzyıl başlarında İzmir Yahudilerinin yegâne dilidir. Henri Nahum, a.g.e., s. $54-55$.

59 Korkmaz Alemdar, "Türkiye'de Yabancı Dilde Basın", Tarih ve Toplum, sayı 57, s. 38-39; Orhan Koloğlu "Türkçe-Dışı Basın", Tanzimattan Cumhuriyete Türkiye Ansiklopedisi, I/97; Esther Benbessa-Aron Rodrigue, Türkiye ve Balkan Yahudileri Tarihi, s. 196.

60 Orhan Koloğlu “Osmanlı Basını: İçeriği ve Rejimi”, Tanzimattan Cumhuriyete Türkiye Ansiklopedisi, I/71-76. 
Tarihsel Süreçte İzmir Yahudi Cemaatinin Sosyo-Kültürel ve Ekonomik Durumu El Nüveliste (Haberci), Esperansa, El Meseret (Sevinç)] bahsedilmekle birlikte, bunlardan ilk dördünün varlığını kanıtlayan bir delil yoktur. 1905 yılında Gad Franko “Lanor”, 1907’de Hizkiya Franko "El Komersiyal" gazetelerini yayınlamaya başlamışlardır. 1909'da çıkarılan "Matbuat ve Matbaalar Kanunu" ile basın ve matbaa üzerindeki denetimler arttırılmıştır. İzmir Yahudileri 1910 yılında "La Boz de İzmir" (İzmir'in Sesi) ve "Bayram"; 1911'de "Ufuk"; 1912' de "El Lavorador"; 1914'te "Les Anneles" isimli gazeteleri yayınlamaya başlamışlardır. Gaz Franko, Selim Mizrahi, Hizkiya Franko gibi yazarlar Hizmet, İttihad, Ahenk ve Köylü gazetelerinde “Osmanlı Birliği" üzerine yazılar yazmışlardır. ${ }^{61}$ Günümüzde cemaate ait günlük veya haftalık bir gazete yoktur ve büyük ölçüde İstanbul'da çıkan Şalom gazetesini takip etmektedirler.

Yahudiler matbaayı Osmanlıya tanitan millettir. Osmanlılardaki ilk matbaayı İber Yarımadasından kovulan Sefarad Yahudileri 1494 'te İstanbul' da kurmuşlardır. Daha sonra Yahudiler 1510'da Selanik'te, 1554 'te Edirne'de, $1605^{\prime}$ te Şam'da ve 1657 ' de İzmir' de ${ }^{62}$ birer matbaa açmışlar63 ve bu matbaalar sayesinde kültürlerini korumuşlardır. ${ }^{64}$ Avraham Ben Yedidya Gabay tarafından kurulan İzmir matbaası 18 yıl hizmet vermiştir. Yona Ben Yaakov Eşkenazi 1700'lerde İzmir' de bir şube açmıştır. Bu tarihten itibaren Osmanl1nın gerilemeye başlaması ile matbaacılık faaliyeti de duraklamaya girmiştir. 1905 yılında İzmir'deki 33 matbaadan üçü; 1908'deki 39 matbaadan ise beşi Yahudilere aitti. Bu matbaalar Türkçe, Fransızca, Rumca, İbranice ve Ermenice dillerinde basım yapmaktayd1. ${ }^{65}$

İzmir Yahudileri, gençlerin kendilerini yetiştirmesi için tarih, coğrafya ve edebiyata ağırlık veren zengin kütüphaneler ve çeşitli amaçlara hizmet etmesi için değişik kültür dernekleri kurmuşlardır.

61 İzmir'de Yahudi basınının gelişimi hakkında ayrıntılı bilgi için bkz., Sara Pardo, a.g.e., s. 46; S. Bora, a.g.e., s. 173-176; Henri Nahum, a.g.e., s. 157-173.

62 Avram Galanti, Türkler ve Yahudiler, s. 148; Henri Nahum, a.g.e., s. 33; Tuncer Baykara, İzmir Şehri ve Tarihi, Ege Üniv. Mat., İzmir, 1974, s. 64.

63 Türklere ait ilk matbaa 1728'de açılmıştır, onun da başmürettibi olan Yona Ben Yaakov Eşkenazi yine bir Yahudi'dir. Avram Galanti, Türkler ve Yahudiler, s. 148.

64 Avram Galanti, Türkler ve Yahudiler, s. 148; Abdurrahman Küçük, Dönmeler Tarihi, Rehber Yay., Ankara, 1992, s. 101.

65 İzmir'de Yahudi matbaacılığı hakkında ayrıntılı bilgi için bkz., S. Bora, a.g.e., s. 181-183. 
Mesela 1894'te kurulan “İspanya'dan Kovulan Musevilerin Gelişinin Dördüncü Asrını Kutlama Cemiyeti" geçmişte çektikleri sıkıntıların unutulmamasını, daima hafızalarda kalmasını, birlik ve beraberliği güçlendirmeyi hedeflemiştir. 1900 yılında kurulan "Tamim-i Lisan-i Osmani Cemiyeti" Türkçenin yaygınlaştırılmasını amaçlarken; 1891 yılında kurulan "Yahudi Musiki Cemiyeti"nin kuruluş gayesi Yahudi bestekârların desteklenmesi ve yenilerinin yetişmesidir. ${ }^{66}$ İzmir Yahudilerinin müzik alanında oldukça yetkin oldukları ve müziğe önem verdikleri dikkati çekmektedir. 18-19. yüzyılda İzmirli meşhur Yahudi bestekârlar arasında Yomtov Danon, Avram Aryas, İlya Levi, İsak Barki sayılabilir. Hayim Alazraki (Şapçı Hayim), Şemtov Şikar (Hoca Santo), Salomon Algazi (Bülbüli Salamon) ve oğlu İsak Algazi ise İzmir'de 20. yüzyıldaki başlıca Yahudi bestekarlarındandır. ${ }^{67}$ Hatırlanacağ1 üzere, 2012 Eurovision şarkı yarışmasında da Can Bonomo isimli bir Yahudi genci Türkiye'yi temsil etmiştir.

\section{IV- İzmir Yahudilerinin Ekonomik Durumları}

İber Yarımadasından sürgün edilen Yahudiler eğitimli ve kültürel açıdan donanımlıydılar. 17. yüzyılda İzmir'de Yahudiler tüccarlık, sarraflık, tefecilik ${ }^{68}$, gümrük memuru, doktorluk, eczacilık, tercümanlık gibi mesleklerle meşgul olmuşlardır. Ege bölgesinin vergisini toplama işini de iki Yahudi yapmaktayd1. ${ }^{69}$ Ziraî işlere rağbet etmeyen Yahudiler, şehir halkının rağbet ettiği her şeyin alım-satımını yapmaktaydılar..$^{70}$ Yahudiler ekonomik açıdan bu üstünlüklerini 18. yüzyıldan itibaren Rumlara ve Ermenilere kaptırmışlardır. 19. yüzyıl sonlarında genç kızlarının çoğu tütün fabrikasında çalışmaktaydılar. ${ }^{71}$ Hatta bu dönemde Yahudiler arasında dilenciliğin

66 İzmir'de Yahudi kütüphaneleri ve kültür dernekleri hakkında ayrıntılı bilgi için bkz., S. Bora, a.g.e., s. 183-184; Sara Pardo, a.g.e., s. 52-53.

67 Bu sanatçılardan Şemtov Şikar, Sultan Abdülhamit'in huzurunda konser vermiştir. Avram Galanti, Türkler ve Yahudiler, s. 118-128; S. Bora, a.g.e., s. 100; Sara Pardo, a.g.e., s. 68-71.

68 Bu tür meslekler insanı yormayan ama çok kazandıran işlerdi ve M. S. Sharon'un Febvre'e dayanarak ifade ettiğine göre bu işlerde sahtekârlık yapmak çok kolaydı. M. S. Sharon, Türkiye Yahudileri-Tarihsel Bakış, Jerusalem, 1982, s. 145; S. Bora, a.g.e., s. 95; Rauf Beyru, a.g.e., s. 13.

69 Henri Nahum, a.g.e., s. 33; Esther Benbessa-Aron Rodrigue, a.g.e., s. 134.

70 Sadiye Tutsak, İzmir'de Ĕ̆itim ve Eğitimciler (1850-1950), Kültür Bakanlı̆̆ı Yay., Ankara, 2002, s. 25.

71 Halid Ziya Uşaklıgil, İzmir Hikâyeleri, s. 174. 
Tarihsel Süreçte İzmir Yahudi Cemaatinin Sosyo-Kültürel ve Ekonomik Durumu yaygınlaştığı, 1873-1874 yıllarında 1000 ailenin dilencilik yaptığı, ifade edilmektedir. ${ }^{72}$

17-18. yüzyıllarda İzmir ticareti tamamen Yahudilerin elindeydi, onların elinden geçmeyen herhangi bir malı alıp-satmak mümkün değildi. ${ }^{73}$ Ancak, Yahudiler 18. yüzyıldan itibaren ticaretteki ve idaredeki rollerini yitirmeye başlamışlardır. Kendini yenilemeyen cemaat, Batı Avrupa'dan göçlerin durması ve Osmanlı'nın devletinin gerilemesiyle birlikte ticarî üstünlüğünü yitirmeye başlamıştır. ${ }^{74}$

İzmir Yahudi cemaatinin içinde bulunduğu sıkıntılardan kurtulmasında İzmir ve kazalarına ayrı bir önem veren Alyans kuruluşu önemli katkı sahibidir. Bu kuruluşun hedeflerine paralel olarak yardımlaşma dernekleri kurulmuştur. Çeşitli meslekî kursların açılmasıyla İzmir Yahudi cemaatinin maddi ve manevi olarak canlanması hedeflenmiştir. Rum cemaatinin ticaretteki tekelciliği Yahudi girişimciliğinin önünü kesmiştir. Meslekî beceri kursları çok işe yaramış; kuruluş iş bulmakta güçlük çeken bazı kalifiye Yahudileri, uluslararası bağlantıları aracılığıyla Arjantin'e yollamıştır. ${ }^{75}$

İzmir hahambaşılığ1 Evlilik Defterine göre, 1910, 1911, 1914 ve 1919 yıllarındaki meslekler ve bu meslekleri yapanların sayılarına örnek olması açısından 1910 yılı meslek dağılımını gösterir tabloyu aşağıda veriyoruz ${ }^{76}$ :

S. Bora, a.g.e., s. 95-97.

73 Rauf Beyru, a.g.e., s. 12; Henri Nahum, a.g.e., s. 41; Esther Benbessa-Aron Rodrigue, a.g.e., s. 150-151.

74 S. Bora, a.g.e., s. 15-16; Esther Benbessa-Aron Rodrigue, a.g.e., s. 148; Bernard Lewis, The Jews of Islam, Routledge, London, 1983, s. 18.

75 S. Bora, a.g.e., s. 98-100; Rauf Beyru, a.g.e., s. 120.

76 Diğer yıllara ait tablolar için bkz., S. Bora, a.g.e., s. 119-123. Daha evvel de ifade ettiğimiz gibi bu defterlerdeki güncel kayıtlara ulaşma şansımız olmadı. 


\begin{tabular}{|c|c|c|c|c|c|c|c|}
\hline Meslek & $\underline{\text { Sayı }}$ & $\underline{\text { Meslek }}$ & $\underline{\text { Sayı }}$ & $\underline{\text { Meslek }}$ & $\underline{\text { Sayı }}$ & $\underline{\text { Meslek }}$ & $\underline{\text { Sayı }}$ \\
\hline Manav & 15 & Çırak & 14 & Terzi & 7 & Çerçi & 7 \\
\hline Ayakkabııı & 7 & Çuvalcı & 5 & Gazeteci & 4 & Tüccar & 4 \\
\hline Eskici & 4 & Meyhaneci & 4 & Garson & 4 & Bakkal & 4 \\
\hline Manifatu- & 4 & Sarraf & 4 & Demirci & 3 & Camcı & 3 \\
\hline Tenekeci & 3 & Arabacı & 3 & Bardakçı & 3 & Bahçıvan & 2 \\
\hline Paçavracı & 2 & Hırdavatçı & 2 & Boyacı & 2 & Çorapçı & 2 \\
\hline Balıkçı & 2 & Komisyoncu & 2 & Marangoz & 2 & Fırçacı & 2 \\
\hline Göz doktoru & 1 & Kırtasiyeci & 1 & Kâtip & 1 & Halıcı & 1 \\
\hline Muhasebeci & 1 & Sakatatçı & 1 & Lastikçi & 1 & Yüncü & 1 \\
\hline Gündelikçi & 1 & Bakırcı & 1 & Aktar & 1 & Kravatçı & 1 \\
\hline Lokantacı & 1 & Mezeci & 1 & Kasap & 1 & Sütçü & 1 \\
\hline Tuhafiyeci & 1 & Buzcu & 1 & Kahveci & 1 & Aşçı & 1 \\
\hline Borsacı & 1 & Çalgıcı & 1 & Terlikçi & 1 & Derici & 1 \\
\hline Sey. Satıcı & 1 & Hamal & 1 & Fanilacı & 1 & Pazarcı & 1 \\
\hline
\end{tabular}

Tablodan da anlaşıldığı üzere, Yahudilerin genellikle kentin ve cemaatin ihtiyaçlarını karşılayacak meslekler seçtikleri görülmektedir. Çırak sayısının fazla olması Alyans'ın açtığı kursların başarılı olduğu yönünde yorumlanmaktadır. Ancak sakatatçı, sütçü, seyyar satıcı, hamal, pazarcı, gündelikçi gibi mesleklerin varlığı bu yorumun tam anlamıyla doğrulanamayacağını göstermektedir. Doktorluk, komisyonculuk, öğretmenlik, tüccarlık gibi meslekler ise zaman içinde artmıştır.

Osmanlı toplumu içerisinde yaşayan topluluklardan Türklerin zâbit, Ermenilerin avukat, Rumların bakkal ve lokantacı, Yahudilerin de simsar olarak tanındı ğ 1 dikkati çeker. ${ }^{77}$ Ancak S. Bora'ya göre, bu çok genel bir tanımlamadır ve özellikle Yahudilerin hepsini bu kategoride değerlendirmek yanlış anlaşılmalara yol açacaktır. Zira zengin ve varlıklı Yahudi tanımı İber yarımadasından göç eden Sefarad Yahudilerini kapsamaktadır. Yerli Yahudilerin birçoğu ise ekonomik açıdan sıkıntı çekmekteydiler. Yahudilerin ticarî etkinliğinin artmasının nedenlerinden bir diğeri Türklerin askerî ve idarî alanlara yönelmeleridir. Batılı tüccarlarla kolay iletişim kurabilecek dilleri bilmeleri, Batı'da önemli ticarî bağlantılarının olması, aracılık işlerinde başarılı olmaları, iyi hesap tutabilmeleri gibi sebepler Yahudileri ticarette diğer milletlere göre bir adım daha öne çıkarmıştır.

77 Avram Galanti, Türkler ve Yahudiler, Tan Mat., İstanbul, 1947, s. 104, 120. 
Tarihsel Süreçte İzmir Yahudi Cemaatinin Sosyo-KüItüreI ve Ekonomik Durumu 16. ve 17. yüzyılda ticarî açıdan parlak ve kazançlı dönemler yaşayan Yahudiler, Osmanlının duraklama ve gerilemeye girdiği dönemlerde ekonomik açıdan zayıflamaya başlamışlardır. 19. yüzyılda Ermenilerin ve Rumların ticaretteki rollerinin artmasıyla Yahudilerin ekonomik sıkıntıları had safhaya ulaşmıştır. ${ }^{78}$ Yahudilerin ticaretteki kaderi Osmanlı Devletinin kaderi ile örtüşmektedir. Osmanlının yükselişte olduğu dönemde ticaretin zirvesine yerleşen Yahudiler, Osmanlının duraklamaya ve gerilemeye başladı̆̆ı dönemde ticaret sektöründe silikleşmeye başlamışlardır.

Yahudiler ticarî açıdan ileride oldukları dönemlerde sanayi ve endüstri alanında da etkinliklerini korumuşlardır. Mesela 16. yüzyılda Selanik ve İstanbul'da savaş alet-edevatı, barut yapımı, dokumacılık gibi sanayi işleri ile meşguldüler. Yeniçerilerin giyim ihtiyacını Selanikli dokumacı Yahudiler karşılamıştır. Ticarî alandaki yükseliş ve gerileme trendi sanayi ve endüstri sahası için de geçerlidir. Ancak 19. asrın sonlarında yeni atılımlar ile sigara kâğıdı, iplik, çuval, incir sandığı ve tuğla üretimi gibi alanlarda Yahudilerin etkin hale geldiği görülmektedir. ${ }^{79} 1800$ 'lü yıllarda İzmir Yahudileri arasında 16 banker varken ${ }^{80}$, bu sayı 20. yüzyılın başlarında ikiye (Davidas Bünyamin Efendi ve Mordehay Levi) düşmüştür. ${ }^{81}$ Kurtuluş savaşını takip eden yıllarda Rum ve Ermeni tüccarların İzmir'i terk etmeleri neticesinde onlarla iş yapan Yahudi tüccarlar maddi kayıplara uğramışlardır. Birçok İzmirli Yahudi İspanyolca ve Portekizcenin konuşulduğu Brezilya, Uruguay ve Arjantin'e göç etmiştir. ${ }^{82} 1940$ 'lı yıllarda İzmir Yahudi topluluğu zengin tüccarların yanı sıra esnaf, memur ve işçi sınıfından oluşuyordu. ${ }^{83}$

78 Yahudilerin ticarî açıdan Osmanlı toplumu içerisinde yükselişleri ve gerilemeleri ile İzmir Yahudi cemaatinin ticarî etkinlikleri hakkında ayrıntılı bilgi için bkz., S. Bora, a.g.e., s. 125-144; Henri Nahum, a.g.e., s. 35.

79 Bu dönemde İzmir'deki 391 fabrikadan dokuzunun Yahudilere ait olduğu ifade edilir. Çınar Atay, Tarih İçinde İzmir, İzmir, 1978, s. 83. Yahudilerin sanayi ve endüstri sahasındaki faaliyetleri için ayrıca bkz., Avram Galanti, Türkler ve Yahudiler, s. 113, 116-117; S. Bora, a.g.e., s. 150-152.

$80 \quad$ S. Bora, a.g.e., s. 152.

81 Bankaların bulundukları yer ve yaptıkları işler için bkz., S. Bora, a.g.e., s. 152.

82 Rifat B. Bali, Cumhuriyet Yillarında Türkiye Yahudileri, s. 230.

83 Rifat B. Bali, a.g.e., s. 437. 
Yahudilerin ziraî işlere çok fazla ilgi gösterdiği söylenemez. Ancak, İzmir Yahudilerinin başkalarına ait tarlalarda yevmiye usulüyle çalıştığı görülmektedir. Durumu iyi olan Yahudiler Manisa, Tire, Nazilli gibi yerlerde tarla, bağ, bahçe satın almışlardır. 1890'larda İzmir ve çevresindeki yaklaşık 900.000 dönümlük arazinin \% 0,05'lik bir kısmı Yahudilere aitti. Alyans, 19. asrın sonlarında tarımsal çıraklık sistemi çerçevesinde Yahudileri tarıma yönelterek en azından karınlarını doyurmalarını sağlamak amacıyla Tarım okulları kurmuştur. ${ }^{84} \mathrm{Bu}$ dönemde teşvik maksadıyla Tevrat'tan tarımla ilgili pasajları ${ }^{85}$ içeren konuşmalar yapılmıştır. ${ }^{86}$

İzmir Yahudi cemaati üyelerinden Moti Katan'ın ifade ettiği üzere, günümüzde cemaat üyelerinin ekonomik durumları oldukça iyidir. Yahudilerin yaptıkları işleri sayıca tespit edebilmek mümkün olmamakla birlikte sanayi, tekstil, turizm, kuruyemiş ticareti gibi alanlarda öne çıkan Yahudiler vardır. Gençlerin büyük ölçüde kendi ilgi alanlarına göre meslek seçtikleri ifade edilmektedir.

\section{Sonuç}

Yahudilerin İzmir'de varlığı iki bin yıldan daha gerilere gitmektedir. Geçen bu uzun süre içerisinde Yahudiler varlığını belli belirsiz sürdüre gelmiştir. Çünkü 15. yüzyıla kadar ki süreç hakkında çok net bilgiler yoktur. Ancak 15. yüzyılın sonlarında göçe zorlandıkları İber yarımadasından Osmanlı topraklarına sığınan Yahudilerin bir kısmının İzmir civarına yerleştiği bilinmektedir. Dinî ve ticarî nedenler, 16. yüzyıldan itibaren, civardaki Yahudileri İzmir'e yönlendirmiştir. Böylece Yahudilerin cemaatlerini ve kurumlarını oluşturdukları bir dönem başlamıştır.

Şüphesiz ki, Yahudiler 1600'lü yıllarda İzmir'de yaşayan tek gayrimüslim halk değildir. Onların dışında Rumlar, Ermeniler ve Batılılar şehrin diğer sakinleridir. Yahudilerin bu milletlerle olan ilişkilerinin şekillenmesinde ticarî faaliyetler önemli rol oynamıştır. Yahudilerle diğer milletler arasında bazen dinî bakış açısından kaynaklanan çatışmalar vuku bulmuştur. Yahudilerin Osmanlı Devleti ile olan ilişkileri büyük ölçüde sorunsuz devam etmiştir. Zaten Türk

84 Yukarıdaki meslek dağılımı tablosunda zikredilen vasıfsız işçiler ve diğer işsizler bu alana yönlendirilmiştir.

85 Tekvin 47/24; Çıkış 23/10-11; Levililer 23/10, 39; 26/20; Tensiye 30/9; Yeremya 29/5, 28 vd.

86 Alyans'ın, Yahudileri kalkındırmak adına benimsediği tarım anlayışı ve açtıkları tarım okulları hakkında bkz., S. Bora, a.g.e., s. 144-150. 
Tarihsel Süreçte İzmir Yahudi Cemaatinin Sosyo-Kültürel ve Ekonomik Durumu ve Yahudi mahallelerinin yan yana konumlanışı bunun bir göstergesi kabul edilir. Yahudiler ve Türkler gündelik yaşamlarını iç içe sürdürmüşlerdir. Yahudiler karşılaştıkları sorunların çözümünde duydukları güvenden ötürü Osmanlı mahkemelerine müracaat etmişlerdir. Bahsettiğimiz bu hususlar, yani bir arada yaşama, aynı okulda okuma, benzer işleri yapma, Yahudilerin Türk yargısına güveni gibi hususlar halen cemaat içerisindeki geçerliliğini korumaktadır. Yahudiler, Osmanlı döneminde konulan kurallara (giyimkuşam gibi) riayet etmişlerdir. Aynı şekilde günümüzde Türk devletinin yasalarına uymakta ve diğer Türk vatandaşları gibi yaşamlarını sürdürmektedirler.

Yahudilerin eğitim-öğretim faaliyetlerine ayrı bir önem verdikleri görülmektedir. Zaten bu, dillerini ve kültürlerini korumalarının en önemli nedenidir. Nitekim Yahudiler matbaayı ilk kuran millettir. Onlar Osmanlı idaresinde değişik dönemlerde hem kendi özel okullarını kurmuşlar hem de diledikleri zaman Osmanlı okullarında eğitim almışlardır. İzmir Yahudilerinin basın faaliyetlerinde de etkin olduğu dikkat çekmektedir. Çıkardıkları gazetelerle cemaati bilinçlendirme ve kültürlü bir nesil yetiştirme gayreti gütmüşlerdir. Günümüzde ise, İzmir'de basılan bir gazete olmadığından cemaatle ilgili haberleri İstanbul ve diğer yerlerdeki yayın organlarından takip etmektedirler.

Yahudiler 16. yüzyılın başlarında diğer milletlerden tüccarların tercümanlığını yapmışlardır. Zamanla kazandıkları tecrübe sayesinde kendi ticarethanelerini kurarak ekonomik açıdan gelişmeye başlamışlardır. Yahudiler 17. yüzyılda şehirde cari olan her türlü ticarî faaliyette pay sahibi olmuşlardır. Bu durum, Yahudilere karşı diğer gayrimüslimlerin tepkisine yol açmıştır. Osmanlı Devletinin duraklama ve gerileme süreçlerinden Yahudilerin ekonomik faaliyetleri de olumsuz etkilenmiştir. Bu dönemde Paris merkezli Alyans Kurumu değişik alanlarda Yahudileri yeniden ayağa kaldırmaya yönelik projeler devreye sokmuştur. Bu kurumsal desteğin kısmen başarılı olduğu söylenebilir. Günümüzde ise, İzmir Yahudileri 1500 civarındaki nüfusuyla gayet müreffeh şekilde, barış ve huzur içerisinde yaşamlarını sürdürmektedirler.

\section{Kaynakça}

Akurgal, Ekrem, Eski İzmir I: Yerleşme Katları ve Athena Tapınağı, Ankara, 1983. 
Alemdar, Korkmaz, "Türkiye'de Yabancı Dilde Basın", Tarih ve Toplum, sayı 57, s. 38-39.

Arslan, Hammet, “Tarih Boyunca İzmir Yahudileri: Yedi Kiliseler, Sürgün, Cemaatleşme Süreci ve Modern Durum", Bütün Yönleriyle Yahudilik Sempozyumu (18-19 Şubat 2012), Türkiye Dinler Tarihi Derneği, Ankara, 2012, s. 187-217.

Atay, Çınar, Tarih İçinde İzmir, İzmir, 1978.

Bali, Rıfat B., Cumhuriyet Yıllarında Türkiye Yahudileri: Bir Türkleştirme Serüveni (1923-1945), İletişim Yay., İstanbul, 2001.

Barnai, Jacob, "Blood Libels in the Ottoman Empire of the Fifteenth to Nineteenth Centuries", Antisemitism Through the Ages, Jerusalem.

Barnai, Jacob, "On the History of the Jews in the Ottoman Empire", Sephardi Jews in the Ottoman Empire, Ed. Esther Juhasz, New York, 1990.

Baykara, Tuncer, İzmir Şehri ve Tarihi, Ege Üniv. Mat., İzmir, 1974.

Benbessa, Esther-Aron Rodrigue, Türkiye ve Balkan Yahudileri Tarihi (14.20. Yüzyıllar), Çev., Ayşe Atasoy, İletişim Yay., İstanbul, 2001.

Besasel, Yusuf, Osmanlı ve Türk Yahudileri, Gözlem Gazetecilik Basın ve Yayın A.Ş., İstanbul, 2004.

Beyru, Rauf, 19. Yüzyılda İzmir'de Yaşam, Literatür Yay., İstanbul, 2000.

Bora, Siren, İzmir Yahudileri Tarihi (1908-1923), Gözlem Gazetecilik Basın ve Yayın A.Ş., İstanbul, 1995.

Canpolat, Emin, İzmir: Kuruluşundan Bugüne Kadar, İstanbul, 1954.

Doğan, Hatice, Osmanlı Devletinde Hahambaşılık Müessesesi, Selçuk Üniv. SBE Yüksek Lisans Tezi, Konya, 2002.

Emecen, Feridun, Unutulmuş Bir Cemaat: Manisa Yahudileri, İstanbul, Eren Yay., 1997.

Emecen, Feridun, XVI. Asırda Manisa Kazası, TTK Basımevi, Ankara, 1989.

Eroğlu, Ahmet Hikmet, Osmanlı Devletinde Yahudiler (XIX. Yüzyılın Sonuna Kadar), Alperen Yay., Ankara, 2000.

Eryılmaz, Bilal, Osmanlı Devletinde Gayrimüslim Teb’anın Yönetimi, Risale, İstanbul, 1990.

Galante, Avram, Histoire de Juifs d'Anatolie, des Juifs d'Izmir, Imprimerie M. Bakok, İstanbul, 1937.

Galanti, Avram, Türkler ve Yahudiler, Tan Mat., İstanbul, 1947.

Galanti, Avram, Fatih Sultan Mehmet Zamanında İstanbul Yahudileri, Fakülteler Mat., İstanbul, 1953.

Güleryüz, Naim, Türk Yahudileri Tarihi I, Gözlem Yay., İstanbul, 1993.

Koçak, Cemil, "Tanzimattan Sonra Özel ve Yabancı Okullar", Tanzimattan Cumhuriyete Türkiye Ansiklopedisi, II/485-486.

Kodaman, Bayram, Abdülhamit Devri Eğitim Sistemi, İstanbul, 1980. 
Tarihsel Süreçte İzmir Yahudi Cemaatinin Sosyo-Kültürel ve Ekonomik Durumu

Koloğlu, Orhan, “Osmanlı Basını: İçeriği ve Rejimi”, Tanzimattan Cumhuriyete Türkiye Ansiklopedisi, I/71-76.

Koloğlu, Orhan, "Türkçe-Dışı Basın”, Tanzimattan Cumhuriyete Türkiye Ansiklopedisi, I/97.

Kurat, Akdes Nimet, Çaka Bey: İzmir ve Civarındaki Adaların İlk Türk Beyi (MS 1081-1096), Ankara, 1966.

Küçük, Abdurrahman, Dönmeler Tarihi, Rehber Yay., Ankara, 1992.

Kütükoğlu, Mübahat S., XV ve XVI. Asırda İzmir Kazasının Sosyal ve İktisâdi Yapısı, İBB Kültür Yayını, İzmir, 2000.

Levi, Avner, Türkiye Cumhuriyeti'nde Yahudiler: Hukuki ve Siyasi Durumları, İletişim Yay., İstanbul, 1996.

Levy, Avigdor, The Sephardim in the Otoman Empire, Darwin Press, New Jersey, 1992.

Lewis, Bernard, The Jews of Islam, Routledge, London, 1983.

Lindau, Paul, "1900'lerde İzmir" Türk Dünyası Araştırmaları, çev. Selçuk Ünlü, İstanbul, s. 179.

Nahum, Henri, İzmir Yahudileri: 19.-20. Yüzyıl, Çev: Estreya Seval Vali, İletişim Yay., İstanbul, 2000.

Nezihi, Raif, İzmir Tarihi, İzmir Büyükşehir Belediyesi Kültür Yay., İzmir, 2001.

Nichols, James Hastings, History of Christianity (1650-1950): Secularization of the West, The Ronald Press Company, New York, 1956.

Okçay, Hale, "İzmir Yahudileri: İşadamlarının Kimliğinin Dönüşümü", Sosyoloji Dergisi, (17), İzmir, s. 191-192.

Okçay, Hale, İzmir Yahudi Cemaati Kadın Kimliği, Phoenix, Ankara, 2013.

Pardo, Sara, Sevgili İzmir Beni Tanı: Dünden Yarına İzmir Yahudileri, Etki Yay., İzmir, 2007.

Rolleston, George, Report on Smyrna, printed by George E. Eyre and William Spottiswoode, London, 1857.

Scholem, Gershom, Sabetay Sevi: Mistik Mesih 1626-1676, Çev. Eşref Bengi Özbilen, Kabalcı Yay., İstanbul, 2011.

Sharon, M. S., Türkiye Yahudileri-Tarihsel Bakış, Jerusalem, 1982.

Tanaç Zeren, Mine, İzmir'de Sefarad Mimarisi ve Sinagogları, Yalın Yay., İstanbul, 2010.

Tanaç, Mine, “İzmir Havraları”, Ege Mimarlık Dergisi, 2001/2-3, Sayı: 38-39, Mimarlar Odası İzmir Şb., Yay., İzmir, 2001.

Tanyu, Hikmet, Tarih Boyunca Türkler ve Yahudiler, Yağmur Yay., İstanbul, 1976, I/92-95.

Tutsak, Sadiye, İzmir'de Eğitim ve Eğitimciler (1850-1950), Kültür Bakanlığ1 Yay., Ankara, 2002.

Uşaklıgil, Halid Ziya, İzmir Hikayeleri, Özgür Yay., İstanbul, 2005.

Uşaklıgil, Halid Ziya, Kırk Yıl, Özgür Yay., İstanbul, 2008. 
Hammet ARSLAN

Ülker, Necmi, XVII. ve XVIII. Yüzyıllarda İzmir Şehri Tarihi, Akademi Kitabevi, İzmir, 1994.

Vahapoğlu, M. Hidayet, Osmanlı' dan Günümüze Azınlık ve Yabancı Okullar, MEB Yay., İstanbul, 2005. 


\section{MiLel VE NiHAL}

inanç, kültür ve mitoloji araştırmaları dergisi

Cilt/Volume: 11 Sayı/Number: 1 Ocak - Haziran / January - June 2014 ISSN: 1304-5482

Bu dergi uluslararası EBSCO HOST Research Databases veri indeksi ve TÜBITTAK-ULAKBİM Sosyal ve Beşeri Bilimler Veri Tabanı tarafından taranmaktadır.

\section{Sahibi / Owner}

Milel ve Nihal Eğitim, Kültür ve Düşünce Platformu Derneği adına Şinasi Gündüz

$$
\begin{gathered}
\text { Yazı İşleri Sorumlusu / Legal Representative } \\
\text { Yasin Aktay }
\end{gathered}
$$

\section{Editör / Editor}

Şinasi Gündüz

Editör Yrd. / Co-Editor

Cengiz Batuk

\section{Yayın Kurulu/ Editorial Board*}

Alpaslan Açıgenç, Ayaz Akkoyun, Yasin Aktay, Mahmut Aydın,

Cengiz Batuk, Şinasi Gündüz, İbrahim Kayan, Hakan Olgun, Necdet Subaşı,

\section{Burhanettin Tatar}

\section{Danışma Kurulu/Advisory Board}

Baki Adam (Prof. Dr., AÜ); Mohd. Mumtaz Ali (Prof. International Islamic U. Malezya); Adnan Aslan (Prof.Dr., Süleyman Şah Ü.); Kemal Ataman (Doç.Dr., Uludağ Ü.); Mehmet Akif Aydın (Prof. Dr., Marmara Ü.); Yılmaz Can (Prof. Dr., OMÜ); Ahmet Çakır (Doç. Dr., OMÜ); Mehmet Çelik

(Prof. Dr., Celal Bayar Ü.); Waleck S. Dalpour (Prof. University of Maine at Farmington); İsmail

Engin (Dr., Berlin); Cemalettin Erdemci (Prof.Dr. YYÜ); Tahsin Görgün (Prof.Dr., 29

Mayıs Ü.) Ahmet Güç (Prof.Dr., Uludağ Ü.); Recep Gün (Doç. Dr., OMÜ); Ö. Faruk Harman

(Prof.Dr., Mar.Ü.); Erica C.D. Hunter (Dr., Cambridge U.); Mehmet Katar (Prof. Dr., A.Ü.);

Mahmut Kaya (Prof. Dr., İ.Ü.); Sadık Kılıç (Prof.Dr., Atatürk Ü.); Şevket Kotan (Y.Doç.Dr., İ.Ü.); İlhan Kutluer (Prof.Dr., Mar. Ü.); George F. McLean (Prof. Catholic Univ., Washington DC); Ahmet Yaşar Ocak (Prof. Dr., Hacettepe Ü.); Jon Oplinger (Prof. University of Maine at Farmington); Ömer Özsoy (Prof.Dr., Frankfurt U.); Roselie Helena de Souza Pereira (Mestre em

Filofia-USP; UNICAMP Brasil); Ekrem Sarıkçıŏlu (Prof.Dr., SDÜ); Hüseyin Sarıŏlu (Prof.Dr.,

İÜ); Bobby S. Sayyid (Dr. Leeds U.); Mustafa Sinanoğlu (Prof.Dr., 29 Mayıs Ü.); Mahfuz Söylemez

(Prof.Dr. IÜ); Necdet Subaşı (Y.Doç.Dr., DİB); Bülent Şenay (Prof.Dr., UÜ); İsmail Taşpınar

(Prof.Dr. Mar.Ü.); C. Sadık Yaran (Prof.Dr., OMÜ); Ali Murat Yel (Prof.Dr., Fatih Ü.); Hüseyin Yılmaz (Doç.Dr., YYÜ); Ali İhsan Yitik (Prof. Dr., DEÜ)

* Soyadına göre alfabetik sıra / In alphabetical order

Kapak ve Sayfa Tasarımı / Cover \& Page Design

İnan Avc1

Baskı / Publication

Ladin Ofset - İstanbul, Mart 2015

2.Mat. Sit. 3 NB 15 Topkapı İstanbul / İsmail Tüz 02125012418

Yönetim Yeri / Administration Place

Milel ve Nihal Eğitim, Kültür ve Düşünce Platformu Derneği

Fevzipaşa Cad. Şehit Mehmet Sarper Alus Sok. No: 5, K.: 3, Tel: (0212) 5339731 Fatih/İstanbul www.milelvenihal.org e-posta: dergi@milelvenihal.org

Milel ve Nihal yılda iki sayı olarak altı ayda bir yayımlanan uluslararası hakemli bir dergidir. Milel ve Nihal' de yayımlanan yazıların bilimsel ve hukuki sorumluluğu yazarlarına aittir. Yayım dili Türkçe ve İngilizce'dir. Yayımlanan yazıların bütün yayın hakları Milel ve Nihal'e ait olup, yayıncının izni olmadan kısmen veya tamamen basılamaz, çoğaltılamaz ve elektronik ortama taşınamaz. Yazıların yayımlanı yayımlanmamasından yayın kurulu sorumludur. 


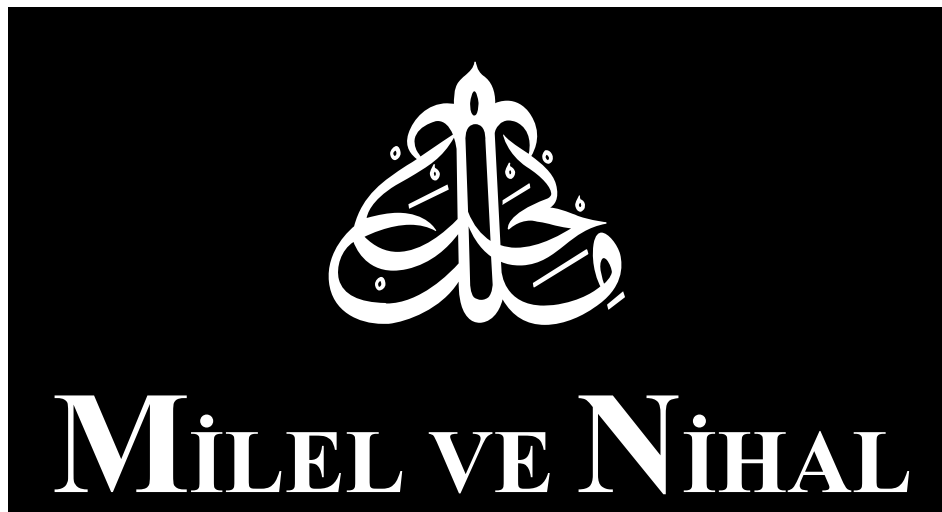

inanç, kültür ve mitoloji araştırmaları derogisi

ISSN: 1304-5482

Cilt/Volume: 11 Sayı/Number: 1

Ocak - Haziran / January - June 2014 